\title{
Toxicological analysis and anti-inflammatory effects of essential oil from Piper vicosanum leaves
}

\author{
Débora Regina Hoff Brait ${ }^{a}$, Márcia Soares Mattos Vaz ${ }^{a}$, Jucicléia da Silva Arrigo ${ }^{a}$, \\ Luciana Noia Borges de Carvalho a , Flávio Henrique Souza de Araújo ${ }^{\text {b }}$, \\ Juliana Miron Vani ${ }^{\mathrm{b}}$, Jonas da Silva Mota ${ }^{\mathrm{c}}$, Claudia Andrea Lima Cardoso ${ }^{\mathrm{c}}$, \\ Rodrigo Juliano Oliveira ${ }^{b}$, Fábio Juliano Negrão ${ }^{a}$, Cândida Aparecida Leite Kassuya a , \\ Arielle Cristina Arena a, d,* \\ a School of Health Sciences, Federal University of Grande Dourados, Dourados, MS, Brazil \\ ${ }^{\mathrm{b}}$ Federal University of Mato Grosso do Sul (UFMS), Campo Grande, MS, Brazil \\ ${ }^{\mathrm{c}}$ Mato Grosso do Sul State University (UEMS), Dourados, MS, Brazil \\ d Department of Morphology, Institute of Biosciences of Botucatu, UNESP - Univ. Estadual Paulista, Botucatu, SP, Brazil
}

\section{A R T I C L E I N F O}

\section{Article history:}

Received 1 September 2015

Received in revised form

27 October 2015

Accepted 28 October 2015

Available online 7 November 2015

\section{Keywords:}

Piperaceae

Piper vicosanum

Essential oil

Acute toxicity

Genotoxicity

Inflammation

\begin{abstract}
A B S T R A C T
This study assessed the anti-inflammatory effects of the essential oil from Piper vicosanum leaves (OPV) and evaluated the toxicological potential of this oil through acute toxicity, genotoxicity and mutagenicity tests. The acute toxicity of OPV was evaluated following oral administration to female rats at a single dose of $2 \mathrm{~g} / \mathrm{kg}$ b.w. To evaluate the genotoxic and mutagenic potential, male mice were divided into five groups: I: negative control; II: positive control; III: $500 \mathrm{mg} / \mathrm{kg}$ of OPV; IV: $1000 \mathrm{mg} / \mathrm{kg}$ of OPV; V: $2000 \mathrm{mg} / \mathrm{kg}$ of OPV. The anti-inflammatory activity of OPV was evaluated in carrageenan-induced pleurisy and paw edema models in rats. No signs of acute toxicity were observed, indicating that the LD50 of this oil is greater than $2000 \mathrm{mg} / \mathrm{kg}$. In the comet assay, OPV did not increase the frequency or rate of DNA damage in groups treated with any of the doses assessed compared to that in the negative control group. In the micronucleus test, the animals treated did not exhibit any cytotoxic or genotoxic changes in peripheral blood erythrocytes. OPV (100 and $300 \mathrm{mg} / \mathrm{kg}$ ) significantly reduced edema formation and inhibited leukocyte migration analyzed in the carrageenan-induced edema and pleurisy models. These results show that OPV has anti-inflammatory potential without causing acute toxicity or genotoxicity.
\end{abstract}

(C) 2015 Elsevier Inc. All rights reserved.

\section{Introduction}

There is considerable interest in identifying new therapeutic agents obtained from plants used in popular medicine. One of the reasons of this interest is that drugs currently available have a number of adverse effects and new strategies are needed to

Abbreviations: OPV, essential oil from P. vicosanum leaves; GC, gas chromatograph; GC-MS, mass spectrometer detector; OECD, Organisation for Economic Cooperation and Development; LD50, median lethal dose; PBS, phosphate buffer-saline; SEM, standard error of the mean; ANOVA, one-way analysis of variance.

* Corresponding author. Department of Morphology, Institute of Biosciences of Botucatu, São Paulo State University (UNESP), Distrito de Rubião Junior, s/n, Caixa Postal - 510, CEP: 18618970, Botucatu, SP, Brazil.

E-mail address: ariellearena@ibb.unesp.br (A.C. Arena). improve treatment (Rates, 2001).

The genus Piper (Piperaceae family) comprises about 2000 species distributed in the tropical and subtropical regions. Piper species have been widely used in folk medicine for the treatment of various diseases such as bronchitis, intestinal pains, skin irritations and inflammation, and in the preparation of ceremonial drinks (Mesquita et al., 2006; Wang et al., 2014). Phytochemical analyses of this genus have demonstrated the occurrence of alkaloids, amides, propenylphenols, lignans, neolignans, steroids, pyrones, chalcones, dihydrochalcones, flavones and terpenoids (Sengupta and Ray, 1987; Parmar et al., 1997).

Although little information is available in the literature on the therapeutic or toxic effects of this plant, studies have shown that extracts obtained from some species of Piper, such as Piper amalago, Piper nigrum, Piper longum, Piper abbreviatum, Piper umbellatum, 
Piper officinarum present therapeutic properties, such as antiinflammatory and antimicrobial activities, hepatoprotective effects, diuretic activity, among others (Rajeswary et al., 2011; Salleh et al., 2012; Novaes et al., 2014; Tasleem et al., 2014; Wan Salleh et al., 2014; Iwamoto et al., 2015). The especially well-studied species regarding their therapeutic activities, the fruits of P. nigrum L., possesses potent analgesic and anti-inflammatory activities, at doses of 10 and $15 \mathrm{mg} / \mathrm{kg}$ and these activities were attributed to piperine, its major alkaloid constituent (Tasleem et al., 2014).

Piper vicosanum Yuncker is a shrub that occurs in the Brazilian Atlantic Forest. The study carried out by Mesquita et al. (2006), revealed that this species possesses volatile oils with valuable biological activities, such as limonene (45.5\%), $\alpha$-pinene (6.1\%), piperitone (3.4\%), $\beta$-caryophyllene (1.4\%), $\alpha$-selinene (3.2\%), Dcadinene $(2.2 \%)$, spathulenol $(0.3 \%)$, caryophyllene oxide $(0.4 \%), \beta$ pinene $(0.2 \%)$, linalool and germacrene $D$ traces, demonstrating the need for further studies about this species. Thus, due to the lack of studies in the literature using the Piper species, this study evaluated the anti-inflammatory effects of the essential oil extracted from $P$. vicosanum leaves (OPV) and determined the toxicological potential of this oil through acute toxicity, genotoxicity and mutagenicity tests.

\section{Materials and methods}

\subsection{Plant material, preparation and isolation of essential oil}

Piper vicosanum leaves ( $5 \mathrm{~kg}$ ) were collected at the Coqueiro Farm, Dourados, MS (latitude 22012'37, 7 "south and longitude 54055'03, 2"west) in August 2014. A voucher specimen was identified by Dr. Elsie Franklin Guimarães and deposited (register: 4412) in the DDMS herbarium of the Federal University of Grande Dourados (UFGD).

The OPV was isolated from $400 \mathrm{~g}$ of fresh leaves by separate hydrodistillation using a Clevenger-type apparatus for $4 \mathrm{~h}$. At the end of each distillation, the oils were collected, dried with anhydrous $\mathrm{Na}_{2} \mathrm{SO}_{4}$, measured, and transferred to glass flasks that were filled to the top and kept at a temperature of $-18{ }^{\circ} \mathrm{C}$ for further analysis. The yield of the obtained oil was from fresh leaves $0.80 \%$. The analyses were performed employing a gas chromatograph (GC2010 Plus, Shimadzu, Kyoto, Japan), mass spectrometer detector (GC-MS 2010 Ultra) using a fused silica capillary column DB-5 (60 m length $\times 025 \mathrm{~mm}$ internal diameter $\times 0.25 \mathrm{~mm}$ thick film). The temperatures of the injector, detector and the transfer line were 250,280 and $300{ }^{\circ} \mathrm{C}$, respectively. The analysis conditions were: injection volume of $1 \mu \mathrm{L}, 1: 20$ split injection, heating ramp of $50{ }^{\circ} \mathrm{C}$ initial temperature reached $280{ }^{\circ} \mathrm{C}$ at $3{ }^{\circ} \mathrm{C} \mathrm{min}-1$ and remained in the final temperature for $10 \mathrm{~min}$. The mass spectrometer scan parameters included electron impact ionization voltage of $70 \mathrm{eV}$, the mass range of $45-650 \mathrm{~m} / \mathrm{z}$ with $0.5 \mathrm{~s}$ sweep range. The identification was carried out using the calculated retention indexes with the same mixture of linear alkane $\left(C_{7}-C_{40}\right)$ as external reference (Van den Dool and Kratz, 1963) associated to the index reported in the literature (Adams, 2001) and analysis of the mass spectra of the samples compared to the databases (NIST21 and WILEY229).

\subsection{Animals}

Adult male Wistar rats (90 days old, weighing approximately $340 \mathrm{~g}, \mathrm{n}=45$ ) and females (60 days old, weighing approximately $300 \mathrm{~g}, \mathrm{n}=10$ ) were used in the acute toxicity and inflammation study. Male Swiss mice (60 days old, weighing 30-40 g, $\mathrm{n}=50$ ) were used in genotoxicity and mutagenicity studies. All animals used in the experiments were provided by the UFGD. The animals were maintained under controlled temperature $\left(23^{\circ} \mathrm{C}\right)$, with a constant $12 \mathrm{~h}$ light-dark cycle and free access to food and water. The experimental procedures were in accordance with the Ethical Principles in Animal Research and approved by the Committee for Ethics in Animal Experimentation at the UFGD (Protocol number 024/2014).

\subsection{Acute oral toxicity}

Acute toxicity studies were carried out using the OECD (Organisation for Economic Co-operation and Development) - Guidelines 425 and ANVISA guidelines (Brazilian Health Surveillance Agency) (ANVISA, 2004; OECD, 2008).

OPV was administered by gavage, at a dose of $2000 \mathrm{mg} / \mathrm{kg}$, to one female rat after $8 \mathrm{~h}$ of fasting. Sequentially, at intervals of $48 \mathrm{~h}$, the same dose was administered to four female rats, totaling five treated animals. Under the same conditions, five females were treated with vehicle (sunflower oil) in order to establish a comparative negative control group (OECD, 2008).

The animals were observed periodically during the first $24 \mathrm{~h}$ after administering the essential oil and then once a day for 14 days. The five parameters of the Hippocratic screening (Malone and Robichaud, 1962) were analyzed: conscious state (general activity); activity and coordination of motor system and muscle toning (response to tail touch and grip, straightening, strength to grab); reflexes (corneal and headset); activities on the central nervous system (tremors, convulsions, straub, sedation, anesthesia and ataxia) and activities on the autonomic nervous system (lacrimation, cyanosis, ptosis, salivation and piloerection). The water and feed consumption and body weight were also recorded daily (OECD, 2008).

At the end of the observation period, all animals were anesthetized (Ketamine and xylazine, 25 and $10 \mathrm{mg} / \mathrm{kg}$, respectively) and killed by decapitation. Organs (heart, lung, spleen, liver, and kidney) were removed, weighed and examined macroscopically.

\subsection{Comet assay and micronucleus test with peripheral blood}

Mice were divided into five groups ( $n=10$ /group). Three groups received OPV, at doses of 500 (group III), 1000 (group IV), or 2000 (group V) $\mathrm{mg} / \mathrm{kg}$ body weight by oral route (gavage). The negative control animals (group I) were exposed to sunflower oil (vehicle) by gavage and to saline $(0.1 \mathrm{~mL} / 10 \mathrm{~g}$ body weight, i.p). The positive control animals (group II) were treated intraperitoneally with cyclophosphamide (Fosfaseron, Filaxis) at a dose of $100 \mathrm{mg} / \mathrm{kg}$ (Navarro et al., 2014). The OPV dosages were based on our determination of the $\mathrm{LD}_{50}$ (median lethal dose), which was higher than $2000 \mathrm{mg} / \mathrm{kg}$. The treatment was performed once, and OPV was dissolved in sunflower oil and cyclophosphamide was dissolved in saline before administration. Cyclophosphamide was used to induce DNA damage, which has already demonstrated in vivo and in vitro genotoxicity activity in mouse bone marrow cells and peripheral blood (Fenech et al., 1999).

For the Comet assay, $24 \mathrm{~h}$ after treatment with OPV, $20 \mu \mathrm{L}$ of blood was collected from each animal of each group. Slides were pre-coated with $5 \%$ agarose, and $20 \mu \mathrm{L}$ of blood of each individual with $120 \mu \mathrm{L}$ of agarose LPM (1.5\%) at $37^{\circ} \mathrm{C}$ were placed on the slide.

The coverslips were removed and the slides immersed in freshly prepared lysis solution with $89 \mathrm{~mL}$ of lysis stock solution $(2.5 \mathrm{M}$ $\mathrm{NaCl}, 100 \mathrm{mM}$ EDTA, 10 mMTris, pH 10 adjusted with $\mathrm{NaOH}, 89 \mathrm{~mL}$ of distilled water and $1 \%$ of sodium lauroylsarcosine), $1 \mathrm{~mL}$ of Triton $\mathrm{X}-100$ and $10 \mathrm{~mL}$ of DMSO, for $1 \mathrm{~h}$ at $4{ }^{\circ} \mathrm{C}$ in the dark. The slides were placed on an electrophoresis chamber filled with buffer $\mathrm{pH}>13(300 \mathrm{mMNaOH}$ and $1 \mathrm{mM}$ EDTA, prepared with a stock 
solution of $10 \mathrm{~N} \mathrm{NaOH}$ and EDTA $200 \mathrm{mM}, \mathrm{pH} 10$ ) at $4{ }^{\circ} \mathrm{C}$ for $20 \mathrm{~min}$ for DNA denaturation. Electrophoresis was performed at $25 \mathrm{~V}$ and $300 \mathrm{~mA}(1.25 \mathrm{~V} / \mathrm{cm})$. The slides were then neutralized with buffer $\mathrm{pH} 7.5(0.4 \mathrm{M}$ Tris $-\mathrm{HCl})$ for three 5-min cycles, air dried, fixed with $100 \%$ ethanol for $10 \mathrm{~min}$. The slides were stained with $100 \mu \mathrm{L}$ of ethidium bromide $(20 \mu \mathrm{g} / \mathrm{mL})$ and covered with a coverslip. The material was examined with a fluorescence microscope, equipped with an excitation filter of 515-560 $\mathrm{nm}$ and a barrier filter of $520 \mathrm{~nm}$ at $40 \times$ magnification.

Each slide was identified and analyzed in a blind test. The cells (200 per animal; 100 for each time-point) were analyzed randomly. The comet findings were classified as follows: class 0 (no damage); class 1 (comet tail shorter than the diameter of the nucleoid); class 2 (comet tail once or twice the diameter of the nucleoid); and class 3 (comet tail more than twice the size of the nucleoid). Comets with a turbid aspect or a head that was too small were excluded from the analyses, as they could represent dead cells (da Silva et al., 2010). A total damage score was determined by multiplying the number of cells assigned to each class of damage by the numeric value of the class and summing all resulting values.

The micronucleus test with pheripheral blood was conducted according to Hayashi et al. (1990). Blood was collected from the tail of animals from all groups ( $\mathrm{n}=10$ animals/group) at 24,48 , and $72 \mathrm{~h}$ after treatment. Slides were previously prepared with $20 \mu \mathrm{L}$ of acridine orange, and $20 \mu \mathrm{L}$ of peripheral blood was added in the center of the prepared slides. Slides were slip covered and stored in a freezer. The slides were examined using blue light fluorescence microscope (488 nm), an orange barrier filter, and magnification of $100 \times$. Two thousand cells per animal (two slides per animal/ treatment) were examined and micronucleated cells were counted. The micronuclei frequency was examined at $24 \mathrm{~h}, 48 \mathrm{~h}$, and $72 \mathrm{~h}$ after treatment.

\subsection{Carrageenan-induced rat pleurisy}

Rats ( $\mathrm{n}=5$ animals/group) were orally treated with OPV (100 and $300 \mathrm{mg} / \mathrm{kg}$ ) or vehicle ( $0.9 \%$ saline - control or naïve group). The positive control group received a dose of $1 \mathrm{mg} / \mathrm{kg}$ of dexamethasone subcutaneously. Pleurisy was induced in experimental groups by intrapleural injection of $100 \mu \mathrm{L}$ of $1 \%$ carrageenan diluted in saline, as previously described (Kassuya et al., 2009). The naïve group received $100 \mu \mathrm{L}$ of sterile saline by intrapleural injection. After $4 \mathrm{~h}$, the animals were euthanized and the pleural cavity was rinsed with $1 \mathrm{~mL}$ phosphate buffer-saline (PBS). An aliquot of $20 \mu \mathrm{L}$ of lavage (exudate) was collected from the pleural cavity, and diluted with Turck (1:20) and used for total leukocyte count in a Neubauer chamber (Kassuya et al., 2009; Santos et al., 2012).

\subsection{Carrageenan-induced rat paw edema}

Rats ( $\mathrm{n}=5$ animals/group) were orally treated with OPV (100 and $300 \mathrm{mg} / \mathrm{kg}$ ) or vehicle. Another group was treated subcutaneously with dexamethasone $(1 \mathrm{mg} / \mathrm{kg})$. After $1 \mathrm{~h}$, the animals received a solution of $50 \mu \mathrm{L}$ carrageenan injection $(300 \mu \mathrm{g} / \mathrm{paw})$ in the right paw. The other paw received the same volume of sterile $0.9 \%$ saline. A plethysmometer was used to measure the paw edema after $1 ; 2 ; 3$ and $4 \mathrm{~h}$ of carrageenan injection. Results were expressed as $\mu \mathrm{L}$ and the difference between right and left paws were quantified as edema (Kassuya et al., 2005).

\subsection{Statistical analyses}

Data are presented as mean \pm standard error of the mean (SEM). Difference among groups was evaluated by analyses of variance (one-way ANOVA) followed by Tukey-Kramer or Newman-Keuls tests. Statistical differences were considered to be significant at $\mathrm{p}<0.05$. Graphs were performed using GraphPad Prism Software (San Diego, CA, U.S.A).

\section{Results}

The gas chromatography/mass spectrometry (GC-MS) analysis identified 60 compounds in the OPV. Most of the compounds were r-elemene (14.16\%), $\alpha$-alaskene (13.44\%) and limonene (9.10\%) (Table 1).

After the acute toxicity test, the dose of $2000 \mathrm{mg} / \mathrm{kg}$ (limit test OECD, 2008) of OPV did not cause the death of any animal. The female rats exposed presented no behavioral changes during the treatment period, as well as no changes in water and food consumption and ponderal evolution were observed, related to the control group (data not shown). No abnormality was found in the organs at necropsy.

Table 2 presents the overall frequency of damaged cells, the division among the classes of damage and score \pm SEM for the comet assay. These results showed that the groups treated with different doses of OPV did not exhibit increase in the frequency of genotoxic damage, when compared to the negative control group. Conversely, these parameters were significantly different from those observed in the positive control group.

Regarding the micronuclei frequency (Table 3), the results indicated that groups treated with OPV exhibited averages similar to those observed in the negative control group (at all time-points), and that these differed from those observed in the positive control group. These data showed that exposure to OPV did not alter the number of micronucleated polychromatic erythrocytes.

One hour after the carrageenan-induced inflammation, the control group continued to show edema, whereas the groups treated with OPV at doses of 100 and $300 \mathrm{mg} / \mathrm{kg}$ showed a significant decrease in edema compared to the control group (Fig. 1A) and this reduction continued after the second, third and fourth hour of observation (Fig. 1B, C and D). The inhibitions were $78 \pm 2 \%$ and $75 \pm 3 \%$ after $2 \mathrm{~h}$ and $80 \pm 2 \%$ and $86 \pm 3 \%$ after $4 \mathrm{~h}$, respectively. The animals treated with dexamethasone, the positive control, showed a significant reduction at all time points, with inhibitions of $93 \pm 7 \%$ after $2 \mathrm{~h}$ and $85 \pm 5 \%$ after $4 \mathrm{~h}$. Additionally, the oral administration of OPV significantly inhibited the leukocyte migration at all doses tested (100 and $300 \mathrm{mg} / \mathrm{kg}$ ), with inhibitions of $70 \pm 3 \%$ and $85 \pm 2 \%$, respectively, and higher inhibition at a dose of $300 \mathrm{mg} / \mathrm{kg}$ (Fig. 2). For the positive control the inhibition was $91 \pm 2 \%$.

\section{Discussion}

Species belonging to the Piperaceae family are well known due to their therapeutic properties in folk medicine (Alves et al., 2008), however, evidenced-based information is limited. To our knowledge, the present study may represent the first research that demonstrates the anti-inflammatory activity of the essential oil of $P$. vicosanum leaves without causing toxic effects.

In this study, the results indicate that acute administration of OPV has low oral toxicity in rats, since no mortality or clinical signs were observed. Thus, the oil tested falls in Class 5 (a substance with oral lethal dose $\left(\mathrm{LD}_{50}\right)$ higher than $2000 \mathrm{mg} / \mathrm{kg}$ ), hence considered of low toxicity (OECD, 2008). Similar results were found by Rodrigues Silva et al. (2008) and da Silva et al. (2014), that after the acute toxicity analysis of other species of Piper (Piper ovatum and $P$. umbellatum) did not observe toxicity signs at doses of $5000 \mathrm{mg} / \mathrm{kg}$ or $2000 \mathrm{mg} / \mathrm{kg}$, respectively.

Despite the therapeutic properties, several medicinal plants have genotoxic or mutagenic effects (Hong and Lyu, 2011; de 
Table 1

Chemical composition of the essential oil of $P$. vicosanum.

\begin{tabular}{|c|c|c|c|c|}
\hline Retention time (min) & Compound & $\mathrm{RI}_{\mathrm{a}}$ & $\mathrm{RI}_{\mathrm{b}}$ & $\%$ \\
\hline 7.675 & $\alpha$-Pinene & 934 & 932 & 1.11 \\
\hline 8.165 & Camphene & 948 & 946 & 0.04 \\
\hline 9.225 & $\beta$-Pinene & 979 & 974 & 1.74 \\
\hline 11.033 & Limonene & 1026 & 1024 & 9.10 \\
\hline 11.293 & Sylvestrene & 1032 & 1030 & 3.18 \\
\hline 11.625 & (E)- $\beta$-Ocimene & 1040 & 1044 & 1.22 \\
\hline 24.815 & Silphinene & 1341 & 1345 & 0.58 \\
\hline 25.349 & $\alpha$-Longipinene & 1354 & 1350 & 0.53 \\
\hline 26.144 & Longicyelene & 1372 & 1371 & 0.81 \\
\hline 26.321 & $\alpha$-Copaene & 1376 & 1374 & 0.26 \\
\hline 26.607 & 2-epi- $\alpha$-Funebrene & 1383 & 1380 & 2.98 \\
\hline 26.906 & $\beta$-Bourbonene & 1390 & 1387 & 0.54 \\
\hline 27.294 & $\alpha$-Chamipinene & 1399 & 1396 & 3.35 \\
\hline 27.893 & Caryophyllene & 1413 & 1417 & 2.51 \\
\hline 28.724 & r-Elemene & 1434 & 1434 & 14.16 \\
\hline 28.899 & $\alpha$-Guaiene & 1438 & 1437 & 1.33 \\
\hline 29.021 & 6,9-Guaiadiene & 1441 & 1442 & 0.47 \\
\hline 29.319 & cis-Muurola-3,5-diene & 1448 & 1448 & 2.14 \\
\hline 29.399 & $\alpha$-Himachalene & 1450 & 1449 & 0.10 \\
\hline 28.899 & $\alpha$-Guaiene & 1438 & 1437 & 1.33 \\
\hline 29.021 & 6,9-Guaiadiene & 1441 & 1442 & 0.47 \\
\hline 29.319 & cis-Muurola-3,5-diene & 1448 & 1448 & 2.14 \\
\hline 29.399 & $\alpha$-Himachalene & 1450 & 1449 & 0.10 \\
\hline 29.876 & $\alpha$-Acoradiene & 1463 & 1464 & 1.85 \\
\hline 30.141 & $\beta$-Acoradiene & 1268 & 1469 & 1.03 \\
\hline 31.055 & cis- $\beta$-Guaiene & 1491 & 1492 & 0.84 \\
\hline 31.233 & cis-Cadine-1,4-diene & 1495 & 1495 & 1.94 \\
\hline 31.362 & $\alpha$-Selinene & 1498 & 1498 & 1.50 \\
\hline 31.870 & $\alpha$-Alaskene & 1511 & 1512 & 13.44 \\
\hline 32.129 & Y-cadineno & 1518 & 1513 & 1.73 \\
\hline 32.432 & $\delta$-cadineno & 1524 & 1522 & 2.10 \\
\hline 32.825 & $\alpha$-Cadinene & 1536 & 1537 & 4.12 \\
\hline 33.052 & r-Cuprenene & 1542 & 1542 & 0.23 \\
\hline 33.233 & Hedycaryol & 1546 & 1546 & 0.28 \\
\hline 33.444 & $\beta$-vetivenene & 1553 & 1554 & 0.25 \\
\hline 34.038 & Palustrol & 1567 & 1567 & 1.18 \\
\hline 34.357 & Spathulenol & 1575 & 1577 & 2.90 \\
\hline 34.961 & Caryophyllene oxide & 1586 & 1582 & 1.51 \\
\hline 35.164 & Viridiflorol & 1596 & 1592 & 1.66 \\
\hline 35.431 & Ledol & 1603 & 1602 & 1.19 \\
\hline 36.357 & 1-epi-Cubenol & 1628 & 1627 & 0.14 \\
\hline 36.490 & Y-Eudesmol & 1631 & 1630 & 0.31 \\
\hline 36.696 & cis-Cadin-4-en-7-ol & 1636 & 1935 & 0.14 \\
\hline 36.842 & epi- $\alpha$-Muurolol & 1641 & 1640 & 1.74 \\
\hline 37.272 & $\alpha$-Cadinol & 1653 & 1652 & 0.43 \\
\hline 37.413 & Valerionol & 1656 & 1656 & 0.69 \\
\hline 37.583 & Allohimachalol & 1661 & 1661 & 2.13 \\
\hline 37.803 & Intermedol & 1666 & 1665 & 0.40 \\
\hline 38.321 & 5-neo-Cedranol & 1682 & 1684 & 0.11 \\
\hline 38.854 & Z-Apritone & 1690 & 1689 & 0.17 \\
\hline 39.376 & 1,4-hydroxy-4,5-dihydro-Caryophyllene & 1710 & 1706 & 0.53 \\
\hline 42.448 & (Z)- $\alpha$-trans-Bergamotolacetate & 1798 & 1794 & 0.19 \\
\hline 42.913 & Vetivenicacid & 1812 & 1811 & 0.38 \\
\hline 43.607 & Cyclopentadecanolide & 1832 & 1832 & 0.36 \\
\hline 43.844 & Eudesm-7(11)-en-4-olacetate & 1839 & 1839 & 0.61 \\
\hline 44.246 & o-methyl $\beta$-Pipitzol & 1851 & 1853 & 0.21 \\
\hline 44.752 & (E)- $\beta$ - Santalolacetate & 1866 & 1867 & 0.15 \\
\hline 46.022 & Evodione & 1904 & 1904 & 0.35 \\
\hline 46.614 & Totarene & 1922 & 1922 & 0.33 \\
\hline 47.514 & Columellarin & 1951 & 1952 & 0.36 \\
\hline 48.409 & Bifloratriene & 1979 & 1977 & 0.31 \\
\hline 50.124 & (Z)-Falcarinol & 2034 & 2035 & 0.14 \\
\hline 51.231 & (Z)Isoeugenylbenzylether & 2071 & 2072 & 0.67 \\
\hline 53.529 & Abienol & 2148 & 2149 & 1.21 \\
\hline
\end{tabular}

RI, retention index.

Almeida et al., 2015), demonstrating the need to assess the genotoxic potential of herbal preparations (Kelber et al., 2014). In the present study, the genotoxic effects of OPV were evaluated using the comet assay, which detects DNA damage produced by chemical and physical agents (Gontijo and Tice, 2003). The OPV treatment did not increase the incidence of comets in all doses tested, indicating lack of genotoxicity of this oil. However, other genotoxicity tests must be performed to confirm this hypothesis.

In addition, the mutagenic effects of OPV were evaluated using the micronucleus test in peripheral blood, in which changes in DNA and/or damage to the spindle can be detected (Fenech, 2000). Moreover, in the present study OPV did not exhibit any mutagenic 
Table 2

Frequency of damage, by the comet assay in mice treated orally with $P$. vicosanum (OPV).

\begin{tabular}{|c|c|c|c|c|c|c|}
\hline \multirow[t]{2}{*}{ Groups } & \multirow[t]{2}{*}{ Damaged cells } & \multicolumn{4}{|c|}{ Classes of damage } & \multirow[t]{2}{*}{ Score } \\
\hline & & 0 & 1 & 2 & 3 & \\
\hline Negative control & $16.70 \pm 1.22^{\mathrm{a}}$ & $83.30 \pm 1.22$ & $11.60 \pm 1.76$ & $5.10 \pm 1.29$ & $0.00 \pm 0.00$ & $21.90 \pm 1.80^{a}$ \\
\hline Positive control & $84.50 \pm 1.32^{b}$ & $15.50 \pm 1.32$ & $42.20 \pm 2.92$ & $35.30 \pm 3.22$ & $7.00 \pm 0.79$ & $133.80 \pm 3.75^{b}$ \\
\hline 500 mg/kg OPV & $15.20 \pm 1.52^{\mathrm{a}}$ & $84.80 \pm 1.52$ & $8.90 \pm 0.72$ & $5.60 \pm 1.24$ & $0.70 \pm 0.33$ & $22.20 \pm 2.56^{a}$ \\
\hline $1000 \mathrm{mg} / \mathrm{kg}$ OPV & $17.20 \pm 2.52^{\mathrm{a}}$ & $82.80 \pm 2.52$ & $9.80 \pm 1.70$ & $5.60 \pm 1.79$ & $1.80 \pm 0.74$ & $26.40 \pm 4.71^{\circ}$ \\
\hline $2000 \mathrm{mg} / \mathrm{kg}$ OPV & $18.30 \pm 2.06^{\mathrm{a}}$ & $81.70 \pm 2.06$ & $13.40 \pm 1.62$ & $3.80 \pm 0.87$ & $1.10 \pm 0.52$ & $24.30 \pm 3.10$ \\
\hline
\end{tabular}

a Values expressed as mean \pm SEM, $n=10$ animals/group. Different letters indicate statistically significant differences ( $p<0.05$; ANOVA/Tukey).

b Significantly different from negative control and OPV groups. Class 0 - no damage; class 1 - tail of comet shorter than the diameter of nucleiod; class 2 - tail of comet once or twice the diameter of nucleoid; class 3 - tail of comet more than twice the diameter of nucleoid.

Table 3

Frequency of micronuclei in mice treated orally with P. vicosanum (OPV).

\begin{tabular}{|c|c|c|c|}
\hline \multicolumn{4}{|l|}{ Groups } \\
\hline & \multicolumn{3}{|l|}{ Time $(\mathrm{h})$} \\
\hline & 24 & 48 & 72 \\
\hline Negative Control & $5.20 \pm 0.47^{a}$ & $5.50 \pm 0.34^{a}$ & $5.10 \pm 0.61^{\mathrm{a}}$ \\
\hline Positive Control & $35.20 \pm 0.60^{\mathrm{b}}$ & $27.90 \pm 0.69^{b}$ & $27.40 \pm 0.79^{b}$ \\
\hline 500 mg/kg OPV & $7.10 \pm 0.58^{a}$ & $7.00 \pm 0.85^{\mathrm{a}}$ & $5.60 \pm 0.54^{a}$ \\
\hline $1000 \mathrm{mg} / \mathrm{kg}$ OPV & $7.70 \pm 0.79^{a}$ & $6.70 \pm 0.63^{\mathrm{a}}$ & $5.80 \pm 0.44^{a}$ \\
\hline $2000 \mathrm{mg} / \mathrm{kg}$ OPV & $8.00 \pm 0.85^{\mathrm{a}}$ & $6.50 \pm 0.62^{\mathrm{a}}$ & $5.30 \pm 0.50^{a}$ \\
\hline
\end{tabular}

${ }^{a}$ Values expressed as mean \pm SEM, $\mathrm{n}=10$ animals/group. Different letters indicate statistically significant differences. ( $p<0.05$; ANOVA/Tukey).

b Significantly different from negative control and OPV groups.

effects 24,48 or $72 \mathrm{~h}$ after oral administration to mice.

The carrageenan-induced paw edema is a widely used method to evaluate nonsteroidal anti-inflammatory drugs. Antiinflammatory drugs initially inhibit the cyclooxygenase enzyme,

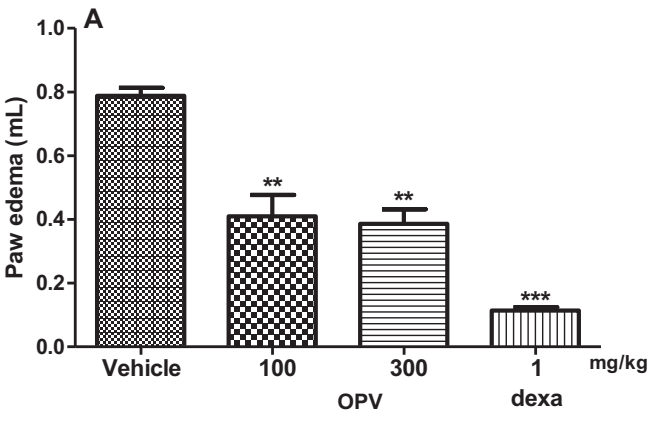

1.0 hour after carrageenan

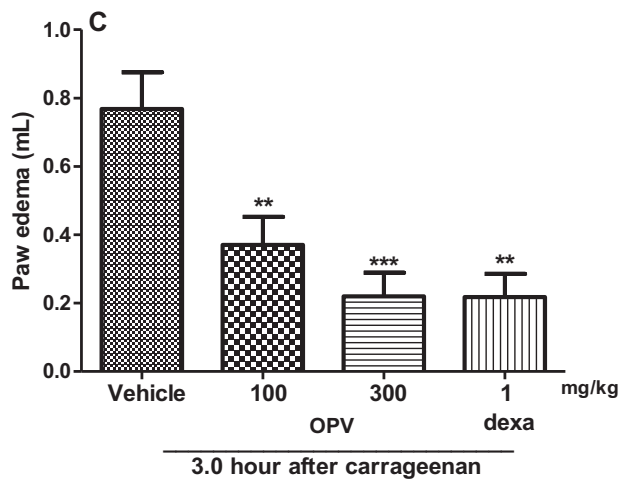

which is involved in prostaglandin synthesis (Anilkumar, 2010). Some species of the Piper genus have been tested for their antiinflammatory activity, showing satisfactory results (de Queiroz et al., 2014; Tasleem, 2014; Iwamoto et al., 2015). The P. nigrum species presented anti-inflammatory activity through the paw edema method and this effect was attributed to presence of piperine (Tasleem, 2014). In our study, reduced carrageenaninduced paw edema was observed in both doses tested and this reduction after 2, 3 and $4 \mathrm{~h}$ of induction was dose-dependent.

The anti-inflammatory activity of OPV also was evaluated using the carrageenan-induced pleurisy model, which can confirm the results obtained by the paw edema test (Vinegar et al., 1973; Almeida et al., 1980). This is a classical test to assess this type of inflammation, forming an exudate in the pleural cavity characterized by infiltration of polymorphonuclear leukocytes, and the release of various important chemical mediators in the inflammatory process (Oliveira et al., 2012).

Anti-inflammatory drugs such as dexamethasone and indomethacin inhibit leukocyte migration between 3 and $6 \mathrm{~h}$ after

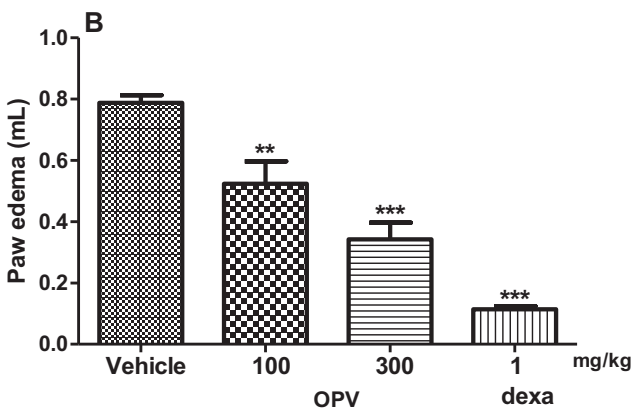

2.0 hour after carrageenan

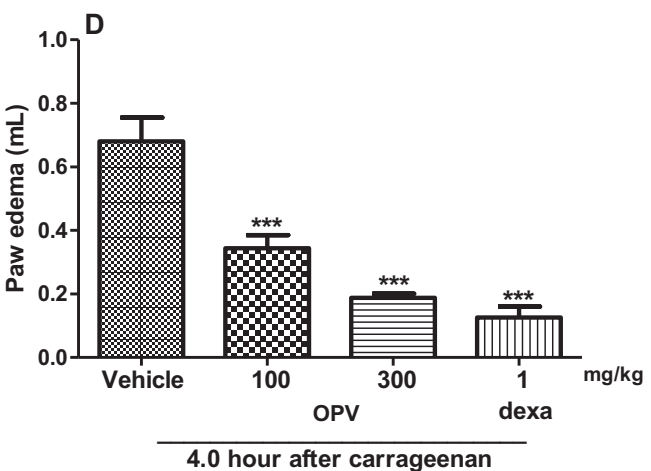

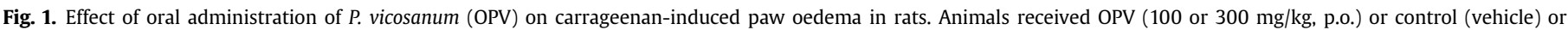

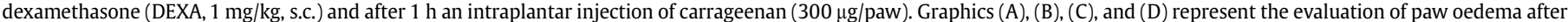

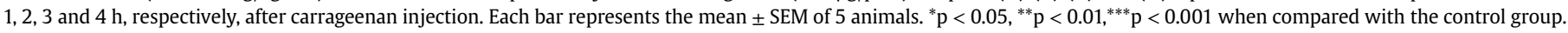
One-way ANOVA followed by the Newman-Keuls test. 


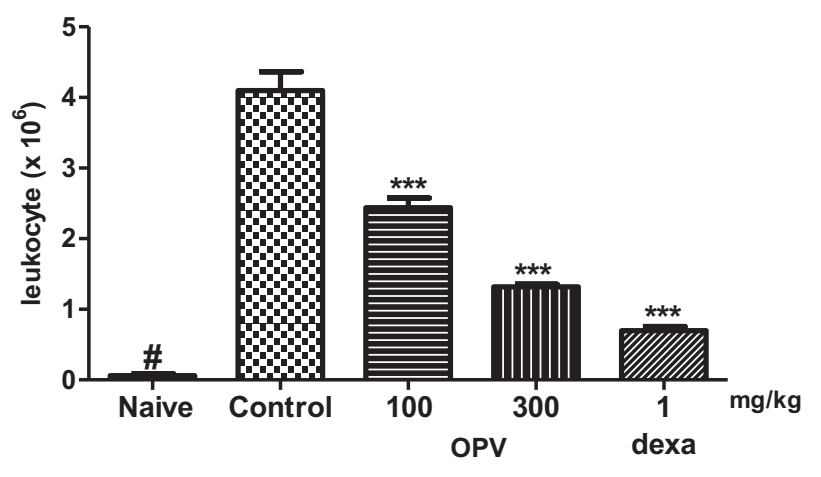

$\overline{4 \text { hours after carrageenan injection }}$

Fig. 2. Effect of oral administration of $P$. vicosanum (OPV) on the inhibition of the leukocyte migration at both doses tested on pleurisy test. Rats were treated $1 \mathrm{~h}$ before an intrapleural injection of carrageenan, with OPV (100 or $300 \mathrm{mg} / \mathrm{kg}$, p.o.), dexamethasone (DEXA, $1 \mathrm{mg} / \mathrm{kg}$, s.c.), or negative control (vehicle, saline solution). Naive group (\# indicate statistic difference from vehicle group) received an intrapleural injection of sterile saline instead of carrageenan and also treated with saline solution. The bars express the mean \pm SEM of 5 animals. ${ }^{\#} \mathrm{p}<0.001$ when compared Naïve treated with negative control; ${ }^{*} \mathrm{p}<0.05,{ }^{* *} \mathrm{p}<0.01$, ${ }^{* * *} \mathrm{p}<0.001$ when compared to negative control group. One-way ANOVA followed by the Newman-Keuls test.

carrageenan administration. Studies performed with the oil of Piper aleyreanum (1-100 $\mathrm{mg} / \mathrm{kg}$, p.o.) in rodents have shown that this oil decreased the total leukocytes count, neutrophils and mononuclear cells, through pleurisy tests, demonstrating the therapeutic potential of this plant (Lima et al., 2012). Similarly, Piper marginatum extract $(0.5$ and $1 \mathrm{~g} / \mathrm{kg}$ ) reduced the paw edema in rats by $80-90 \%$ in relation to the control group, but had a minor effect on the exudate volume and leukocytes migration in carrageenan-induced pleurisy (D'Angelo et al., 1997). However, in another study, Rodrigues Silva et al. (2008), found no anti-inflammatory activity in the hydroethanolic extract of $P$. ovatum leaves $(500 \mathrm{mg} / \mathrm{kg})$, since this extract did not reduce the pleural exudate volume.

In the present study, the treatment with OPV was able to significantly decrease the pleural exudate volume and the leukocyte recruitment in the pleural cavity at the two doses tested, and this effect was dose-dependent. These results, together with the paw edema test, reinforce the anti-inflammatory potential of this species.

Essential volatile oils, characteristic of most species of this genus, have also been object of several studies, revealing valuable biological activities and interesting compositions with monoterpenoids, sesquiterpenoids and seldom phenyl- and arylpropanoids (Mesquita et al., 2006). According to Mesquita et al. (2006), the composition of $P$. vicosanum leaves was dominated by monoterpenoids, with limonene and 1.8-cineole as major compounds. These data corroborate the results obtained in this study, in which the predominance of monoterpenoids (limonene) was identified in the OPV, in addition to sesquiterpenoids ( $\Upsilon$-elemene and $\alpha$-alaskene). It has been shown that D-limonene has immunomodulatory activity and inhibits the proinflammatory activities of CD4 + and CD8 + T lymphocytes (Lappas and Lappas, 2012) and exhibits antimicrobial effects, while $\beta$-elemene has potent anti-proliferation effects on some types of cancer cells (Lu et al., 2012). Thus, for these therapeutic properties, these compounds may be responsible for the effects found in this study.

The essential oil of $P$. vicosanum leaves showed antiinflammatory activity which may be associated with the presence of most of the compounds identified in this study, such as limonene, $\Upsilon$-elemene and $\alpha$-alaskene. Furthermore, OPV did not cause acute toxicity, genotoxicty or mutagenicity. More studies should be carried out to assess the exact mechanism of action responsible for the anti-inflammatory activity, as well as other aspects of toxicity.

\section{Acknowledgments}

The authors thank CAPES for the financial assistance.

\section{Transparency document}

Transparency document related to this article can be found online at http://dx.doi.org/10.1016/j.yrtph.2015.10.028.

\section{Conflict of interest}

The authors declare that there are no conflicts of interest.

\section{References}

Adams, R.P., 2001. Identification of Essential Oil Components by Gas Chromatography/Mass Spectrometry, fourth ed.

Almeida, A.P., Bayer, B.M., Horakova, Z., Beaven, M.A., 1980. Influence of indomethacin and other anti-inflammatory drugs on mobilization and production of neutrophils: studies with carrageenan-induced inflammation in rats. J. Pharmacol. Exp. Ther. 214 (1), 74-79.

Alves, E.O., Mota, J.H., Soares, T.S., Vieira, M.C., Silva, C.B., 2008. Etnobotanical survey and medicinal plants characterization in forest fragments in Dourados-MS Ciênc. Agrotec. 32 (2).

Anilkumar, M., 2010. Ethnomedicinal plants as anti-inflammatory and analgesic agents. In: Ethnomedicine: a Source of Complementary Therapeutics, pp. 267-293. Debprasad Chattopadhyay.

Brazilian Health Surveillance Agency (ANVISA), 2004. Resolution RE-90 Guide for Conducting Pre-clinical Studies of Herbal Toxicity.

D'Angelo, L.C., Xavier, H.S., Torres, L.M., Lapa, A.J., Souccar, C., 1997. Pharmacology of Piper marginatum Jacq. a folk medicinal plant used as an analgesic, antiinflammatory and hemostatic. Phytomedicine 4 (1), 33-40.

da Silva, C.J., dos Santos, J.E., Satie Takahashi, C., 2010. An evaluation of the genotoxic and cytotoxic effects of the anti-obesity drugs sibutramine and fenproporex. Hum. Exp. Toxicol. 29, 187-197.

da Silva, I.F., de Oliveira, R.G., Mendes Soares, I., da Costa Alvim, T., Donizeti Ascêncio, S., de Oliveira Martins, D.T., 2014. Evaluation of acute toxicity, antibacterial activity, and mode of action of the hydroethanolic extract of Piper umbellatum L. J. Ethnopharmacol. 151, 137-143.

de Almeida, P.M., de Sousa Araújo, S., Marin-Morales, M.A., Benko-Iseppon, A.M., Brasileiro-Vidal, A.C., 2015. Genotoxic potential of the latex from cotton-leaf physicnut (Jatropha gossypiifolia L.). Genet. Mol. Biol. 38, 93-100.

de Queiroz, A.C., Alves, H.daS., Cavalcante-Silva, L.H., Dias, T.deL., Santos, M.daS., Melo, G.M., Campesatto, E.A., Chaves, M.C., Alexandre-Moreira, M.S., 2014 Antinociceptive and anti-inflammatory effects of flavonoids PMT1 and PMT2 isolated from Piper montealegreanum Yuncker (Piperaceae) in mice. Nat. Prod. Res. 28 (6), 403-406.

Fenech, M., Holland, N., Chang, W.P., Zeiger, E., Bonassi, S., 1999. The human micronucleus project-an international collaborative study on the use of the micronucleus technique for measuring DNA damage in humans. Mutat. Res. 428, 271-283.

Fenech, M., 2000. The in vitro micronucleus technique. Mutat. Res. 455, 81-95.

Gontijo, A., Tice, R., 2003. In: Ribeiro, L.M., Salvadori, D.M.F., Marques, E.K. (Eds.), Teste do cometa para detecção de danos no DNA e reparo em células individualizadas. ULBRA, Canoas, pp. 247-280.

Hayashi, M., Morita, T., Kodama, Y., Sofuni, T., Ishidate, M., 1990. The micronucleus assay with mouse peripheral blood reticulocytes using acridine orange-coated slides. Mutat. Res. 245, 245-249.

Hong, C.E., Lyu, S.Y., 2011. Genotoxicity detection of five medicinal in Nigeria. J. Toxicol. Sci. 36 (1), 87-93.

Iwamoto, L.H., Vendramini-Costa, D.B., Monteiro, P.A., Ruiz, A.L., Sousa, I.M., Foglio, M.A., de Carvalho, J.E., Rodrigues, R.A., 2015. Anticancer and antiinflammatory activities of a standardized dichloromethane extract from Piper umbellatum L. leaves. Evid. Based Complement. Altern. Med. 2015, 948737.

Kassuya, C.A., Cremoneze, A., Barros, L.F., Simas, A.S., Lapa, F.da R., Mello-Silva, R. Stefanello, M.E., Zampronio, A.R., 2009. Antipyretic and anti-inflammatory properties of the ethanolic extract, dichloromethane fraction and costunolide from Magnolia ovata (Magnoliaceae). J. Ethnopharmacol. 124 (3), 369-376.

Kassuya, C.A., Leite, D.F., de Melo, L.V., Rehder, V.L., Calixto, J.B., 2005. Anti-inflammatory properties of extracts, fractions and lignans isolated from Phyllanthus amarus. Planta Med. 71 (8), 721-726.

Kelber, O., Wegener, T., Steinhoff, B., Staiger, C., Wiesner, J., Knöss, W., Kraft, K., 2014 Assessment of genotoxicity of herbal medicinal products: application of the "bracketing and matrixing" concept using the example of Valerianae radix (valerian root). Phytomedicine 21 (8-9), 1124-1129.

Lappas, C.M., Lappas, N.T., 2012. D-Limonene modulates T lymphocyte activity and 
viability. Cell Immunol. 279 (1), 30-41.

Lima, D.K. Ballico, L.J., Rocha Lapa, F., Gonçalves, H.P., de Souza, L.M., Iacomini, M. Werner, M.F., Baggio, C.H., Pereira, I.T., da Silva, L.M., Facundo, V.A., Santos, A.R., 2012. Evaluation of the antinociceptive, anti-inflammatory and gastric antiulce activities of the essential oil from Piper aleyreanum C.DC in rodents. J. Ethnopharmacol. 142 (1), 274-282.

Lu, J.J., Dang, Y.Y., Huang, M., Xu, W.S., Chen, X.P., Wang, Y.T., 2012. Anti-cance properties of terpenoids isolated from Rhizoma curcumae-a review. J. Ethnopharmacol. 143 (2), 406-411.

Malone, M.H., Robichaud, R.C., 1962. A hippocratic screen for pure or crude drug materials. Llordya 25, 320-331.

Mesquita, J.M.O., Oliveira, A.B., Braga, F.C., Lombardi, J.A., Cunha, A.P., Salgueiro, L. Cavaleiro, C., 2006. Essential oil constituents of Piper vicosanum Yuncker fron the Brazilian Atlantic Forest. J. Essent. Oil Res. 18, 392-395.

Navarro, S.D., Beatriz, A., Meza, A., Pesarini, J.R., Gomes, R.daS., Karaziack, C.B. Cunha-Laura, A.L., Monreal, A.C., Romão, W., Lacerda, Júnior V., Mauro, M.de O. Oliveira, R.J., 2014. A new synthetic resorcinolic lipid 3-heptyl-3,4,6 trimethoxy-3H-isobenzofuran-1-one: evaluation of toxicology and ability to potentiate the mutagenic and apoptotic effects of cyclophosphamide. Eur. J. Med. Chem. 75, 132-142.

Novaes, A.S., da Silva Mota, J., Barison, A., Veber, C.L., Negrão, F.J., Kassuya, C.A., de Barros, M.E., 2014. Diuretic and antilithiasic activities of ethanolic extract from Piper amalago (Piperaceae). Phytomedicine 21 (4), 523-528.

Oliveira, A.M., Conserva, L.M., Ferro, J.N.S., Brito, F.A., Lemos, R.P.L., Barreto, E., 2012. Antinociceptive and anti-inflammatory effects of octacosanol from the leaves of Sabicea grisea var. grisea in mice. Int. J. Mol. Sci. 13 (2), 1598-1611.

Organisation for Economic Co-operation and Development (OECD), 2008. Guidelines for Testing of Chemical, Guideline 425. Acute Oral Toxicity-up-and-downprocedure (UDP) (Paris).

Parmar, V.S., Jain, S.C., Bisht, K.S., Jain, R., Taneja, P., Jha, A., Tyagi, O.D., Prasad, A.K. Wengel, J., Olsen, C.E., Boll, P.M., 1997. Phytochemistry of the genus Piper. Phytochemistry 46 (4), 597-673.
Rajeswary, H., Vasuki, R., Samudram, P., Geetha, A., 2011. Hepatoprotective action of ethanolic extracts of Meliaazedarach Linn. and Piper longum Linn and their combination on $\mathrm{CCl} 4$ induced hepatotoxicity in rats. Indian. J. Exp. Biol. 49 (4), $276-281$.

Rates, S.M.K., 2001. Plants as source of drugs. Toxicon 39 (5), 603-613.

Rodrigues Silva, D., Baroni, S., Svidzinski, A.E., Bersani-Amado, C.A., Cortez, D.A., 2008. Anti-inflammatory activity of the extract, fractions and amides from the leaves of Piper ovatum Vahl (Piperaceae). J. Ethnopharmacol. 116, 569-573.

Salleh, W.M., Ahmad, F. Yen, K.H., Sirat, H.M., 2012. Chemical compositions, antioxidant and antimicrobial activity of the essential oils of Piper officinarum (Piperaceae). Nat. Prod. Commun. 7, 1659-1662.

Santos, J.A., Arruda, A., Silva, M.A., Cardoso, C.A., Vieira, M.C., Kassuya, C.A. Arena, A.C., 2012. Anti-inflammatory effects and acute toxicity of hydroethanolic extract of Jacaranda decurrens roots in adult male rats. J. Ethnopharmacol. 144, 802-805.

Sengupta, S., Ray, A.B., 1987. The chemistry of Piper species: a review. Fitoterapia 58, 147-166.

Tasleem, F., Azhar, I., Ali, S.N., Perveen, S., Mahmood, Z.A., 2014. Analgesic and antiinflammatory activities of Piper nigrum L. Asian. pac. J. Trop. Med. 7S1, S461-S468.

Van den Dool, H., Kratz, P.D., 1963. A generalization of the retention index system including linear temperature programmed gas-liquid partition chromatography. J. Chromatogr. 11, 463-471.

Vinegar, R., Truax, J.F., Selph, J.L., 1973. Some quantitative temporal characteristic of carrageenin-induced pleurisy in the rat. Proc. Soc. Exp. Biol. Med. 143 (3), $711-714$.

Wan Salleh, W.M., Ahmad, F., Yen, K.H., 2014. Chemical compositions and antimicrobial activity of the essential oils of Piper abbreviatum, P. erecticaule and P. lanatum (Piperaceae). Nat. Prod. Commun. 9 (12), 1795-1798.

Wang, Y.H., Morris-Natschke, S.L., Yang, J., Niu, H.M., Long, C.L., Lee, K.H., 2014 Anticancer principles from medicinal piper (hú jiao) plants. J. Tradit. Complement. Med. 4 (1), 8-16. 